\title{
A critical analysis of testosterone supplementation therapy and cardiovascular risk in elderly men
}

\author{
Jason Scovell, BBA, Ranjith Ramasamy, MD; ${ }^{*}$ Jason R. Kovac, MSc, MD, PhD, FRCSC ${ }^{\dagger}$
}

*Scott Department of Urology, Baylor College of Medicine, Houston, TX; † Urology of Indiana, Greenwood, IN

Cite as: Can Urol Assoc J 2014;8(5-6):e356-7. http://dx.doi.org/10.5489/cuaj.1962 Published online May 21, 2014.

$\mathrm{H}$ ypogonadism has become a common diagnosis in elderly men, with increasing prevalence from $20 \%$ in the sixth decade of life to $50 \%$ in the ninth. ${ }^{1,2}$ Declines in serum testosterone affect up to $40 \%$ of men; ${ }^{3,4}$ about $3.75 \%$ of men $\geq 60$ years of age are on some form of testosterone supplementation therapy (TST)., ${ }^{3,5-7}$

The use of TST in elderly men has been justified given that hypogonadism is an independent risk factor for cardiovascular disease and all-cause mortality. ${ }^{8-11}$ Furthermore, improvements following TST in body weight, waist circumference, ${ }^{12-18} \mathrm{HbA} 1 \mathrm{c},{ }^{17,19}$ and total cholesterol levels ${ }^{17,18}$ contribute to decreases in cardiovascular adverse events (CVAEs). However, several recent population-based studies have raised concerns regarding the safety of TST in elderly ( $\geq 65$ years old) men. ${ }^{20-23}$

The first study to identify an association between TST and cardiovascular risk was the Testosterone in Older Men (TOM) trial. ${ }^{20}$ The TOM trial was designed to evaluate muscle strength improvements in men aged $\geq 65$ years $(n=209)$ with limited mobility. The authors included frail men with mobility limitations, including difficulty walking 2 blocks or climbing 10 steps. ${ }^{20}$ Since the study was designed to examine strength improvements, treatment was solely based on serum total testosterone and free testosterone values without considering hypogonadal symptoms. ${ }^{20}$ The trial was halted due to CVAEs ranging from elevated blood pressure $(n=3)$ and peripheral edema $(n=5)$ to stroke $(n=1)$ and myocardial infarction (MI) (non-fatal $n=2$, fatal $n=1) \cdot{ }^{20}$ The greatest concerns arose given the increased number of CVAEs in men on TST $(n=23)$ compared to placebo $(n=5) .{ }^{20}$ While drawing attention to the use of TST in elderly men, the TOM trial was not designed to address CVAEs. Furthermore, there were no differences in the number of serious, life-threatening adverse events between the testosterone and placebo arms of the study. Given that many men reached supra-physiological levels of serum testosterone, and a disproportionate amount of CVAEs occurred in these patients, correlates were drawn.
Recently, several studies have examined the relationship between CVAEs and TST in more detail. For example, a meta-analysis by $\mathrm{Xu}$ and colleagues ${ }^{24}$ noted an increased risk of CVAEs in men on TST (odds ratio 1.54, $p<0.05$ ). Another large $(n=8709)$ retrospective national cohort study in elderly males ( $\geq 60$ years old) analyzed TST outcomes in hypogonadal men (serum testosterone $<300 \mathrm{ng} / \mathrm{dL}$ ) with previous coronary angiography. ${ }^{22}$ In this study, men who began TST had an absolute risk increase of $5.8 \%(p<0.05)$ for a CVAE when compared to matched peers not receiving TST. ${ }^{22}$ Unfortunately, one of the major drawbacks of the study was that despite TST, most men remained hypogonadal (mean serum testosterone $332.2 \mathrm{ng} / \mathrm{dL}$; delta $=175.5 \mathrm{ng} / \mathrm{dL}$ from baseline). ${ }^{22}$ Furthermore, $17.6 \%$ of patients in the testosterone group filled only 1 prescription and no testosterone levels were measured after therapy, which raised the question of therapy adherence and the generalizability of the findings.

In another study, Finkle and colleagues ${ }^{21}$ determined that men $\geq 65$ years old had an increased risk of non-fatal MI within 90 days of TST initiation. In this trial, the pre-TST prescription Ml-event rate in men $\geq 65$ years old was 5.27 (95\% confidence interval $\mathrm{Cl}] 3.81-7.27) .{ }^{21}$ Following the start of TST, these rates increased to $11.52(95 \% \mathrm{Cl} 7.43-$ 17.86 ) in men $\geq 65$, while men $<65$ did not change (pre-TST Ml-event rate of $3.22 \mathrm{Cl} 2.75-3.77$ vs. post-TST MI-event rate of $3.76 \mathrm{Cl} 2.81-5.04) .{ }^{21}$ Unfortunately, in this population-based study, the lack of evaluation of serum hormones and hematocrit levels significantly limited the validity of the conclusions regarding the relationships between TST, serum testosterone and MI. In addition, men on TST were compared to men using PDE5 inhibitors, which is potentially confounding since PDE5 inhibitors benefit men with coronary artery disease, hypertension, heart failure, pulmonary arterial hypertension, and diabetes mellitus. ${ }^{25}$

Currently, the exact mechanisms for increased CVAEs in men on TST remain unknown. Testosterone stimulates erythropoiesis in a dose-dependent manner - an effect that is more prominent in elderly men. ${ }^{26}$ TST also induces a hypercoagulable state via increases in thromboxane $\mathrm{A}_{2}$ and platelet thromboxane $\mathrm{A}_{2}$ receptor density with decreases in prosta- 
glandins. ${ }^{27}$ In the Tampere Adult Population Cardiovascular Risk study (TAMRISK), the authors demonstrated a relationship between borderline polycythemia and an increased risk of cardiovascular mortality. ${ }^{28,29}$ Taken together, it is tempting to speculate that TST may exacerbate cardiac risks in men with atherosclerosis by increasing blood viscosity and platelet counts leading to CVAEs in susceptible elderly patients.

A further factor to consider is the level of serum testosterone in the aging male since it appears that both sub-, and supra-physiological levels of testosterone carry risk. This was illustrated in the population-based cohort study recently done on 3690 men. ${ }^{30,31}$ The authors found that men whose serum testosterone was in the middle 2 quartiles (Q2 and Q3; testosterone $283 \mathrm{ng} / \mathrm{dL}$ to $453 \mathrm{ng} / \mathrm{dL}$ ) of the population had the lowest incidence of death from any cause (Q2 vs. Q1, adjusted hazard ratio [HR] 0.82; Q3 vs. Q1, HR 0.78; Q4 vs. Q1, HR 0.86). ${ }^{30}$

In summary, the preponderance of the evidence suggests that TST should be used judiciously in elderly males, with a paradigm focused on returning serum testosterone levels to normal limits, rather than treating with supra-physiological doses (i.e., injections). Furthermore, it is essential to choose the proper TST modality and to schedule regular (i.e., every 3 months) visits to monitor hematocrit, platelet and serum estradiol levels with an experienced TST specialist.

Competing interests: Dr. Scovell, Dr. Ramasamy and Dr. Kovac all declare no competing financial or personal interests.

This paper has been peer-reviewed.

\section{References}

1. Harman SM, Metter EJ, Tobin JD, et al. Longitudinal effects of aging on serum total and free testosterone levels in healthy men. J Clin Endocrinol Metab 2001;86:724-31. http://dx.doi.org/10.1210/ icem.86.2.7219

2. Surampudi PN, Wang C, Swerdloff R. Hypogonadism in the aging male diagnosis, potential benefits, and risks of testosterone replacement therapy. Int J Endocrinol 2012;2012:625434.

3. Mulligan T, Frick MF, Zuraw QC, et al. Prevalence of hypogonadism in males aged at least 45 years: The HIM study. Int J Clin Pract 2006;60:762-9. http://dx.doi.org/10.1111/j.1742-1241.2006.00992.x

4. Wu FC, Tajar A, Beynon JM, et al. Identification of late-onset hypogonadism in middle-aged and elderly men. N Engl J Med 2010;363:123-35. http://dx.doi.org/10.1056/NEJMoa0911101

5. Baillargeon J, Urban RJ, Ottenbacher KJ, et al. Trends in androgen prescribing in the United States, 2001 to 2011. JAMA Intern Med 2013;173:1465-6. http://dx.doi.org/10.1001/jamainternmed.2013.6895

6. Bassil N, Alkaade S, Morley JE. The benefits and risks of testosterone replacement therapy: A review. Ther Clin Risk Manag 2009;5:427-48.

7. Nigro N, Christ-Crain M. Testosterone treatment in the aging male: myth or reality? Swiss Med Wkly 2012;142:w13539.

8. Corona $G$, Mannucci E, Petrone L, et al. Psychobiological correlates of smoking in patients with erectile dysfunction. Int J Impot Res 2005;17:527-34. http://dx.doi.org/10.1038/si.jii.3901351

9. Corona $G$, Rastrelli $G$, Balercia $G$, et al. Testosterone and cardiovascular risk in patients with erectile dysfunction. J Endocrinol Invest 2012;35:809-16.

10. Kaufman JM, Vermeulen A. The decline of androgen levels in elderly men and its clinical and therapeutic implications. Endocr Rev 2005;26:833-76. http://dx.doi.org/10.1210/er.2004-0013
11. Maggio M, Basaria S. Welcoming low testosterone as a cardiovascular risk factor. Int I Impot Res 2009;21:261-4. http://dx.doi.org/10.1038/iiir.2009.25

12. Moncada I. Testosterone and men's quality of life. Aging Male 2006;9:189-93. http://dx.doi. org/10.1080/13685530601003180

13. Snyder PJ, Peachey H, Berlin JA, et al. Effects of testosterone replacement in hypogonadal men. J Clin Endocrinol Metab 2000;85:2670-7.

14. Wang C, Alexander G, Berman N, et al. Testosterone replacement therapy improves mood in hypogonadal men-a clinical research center study. J Clin Endocrinol Metab 1996;81:3578-83.

15. Wang C, Cunningham G, Dobs A, et al. Long-term testosterone gel (AndroGel) treatment maintains beneficial effects on sexual function and mood, lean and fat mass, and bone mineral density in hypogonadal men. J Clin Endocrinol Metab 2004;89:2085-98. http://dx.doi.org/10.1210/ic.2003-032006

16. Yassin AA, Saad F. Improvement of sexual function in men with late-onset hypogonadism treated with testosterone only. J Sex Med 2007;4:497-501. http://dx.doi.org/10.1111/j.1743-6109.2007.00442.x

17. Hackett $G$, Cole N, Bhartia $M$, et al. Testosterone replacement therapy improves metabolic parameters in hypogonadal men with type 2 diabetes but not in men with coexisting depression: The BLAST Study. J Sex Med 2014;11:840-56. http://dx.doi.org/10.1111/ism.12404. Epub 2013 Dec 6.

18. He J, Bhasin S, Binder EF, et al. Cardiometabolic risks during anabolic hormone supplementation in older men. Obesity (Silver Spring) 2013;21:968-75. http://dx.doi.org/10.1002/oby.20081

19. Corona $G$, Monami $M$, Rastrelli $G$, et al. Type 2 diabetes mellitus and testosterone: A meta-analysis study. Int J Androl 2011;34:528-40. http://dx.doi.org/10.1111/i.1365-2605.2010.01117.x

20. Basaria $S$, Coviello AD, Travison $T G$, et al. Adverse events associated with testosterone administration. $N$ Engl J Med 2010;363:109-22. http://dx.doi.org/10.1056/NEJMoa1000485

21. Finkle W, Greenland S, Ridgeway G. Increased risk of non-fatal myocardial infarction following testosterone therapy prescription in men. PLOS One 2014;9:e85805. http://dx.doi.org/10.1371/journal. pone. 0085805

22. Vigen $\mathrm{R}, \mathrm{O}^{\prime}$ Donnell $\mathrm{Cl}$, Baron $\mathrm{AE}$, et al. Association of testosterone therapy with mortality, myocardial infarction, and stroke in men with low testosterone levels. JAMA 2013;310:1829-36. http://dx.doi. org/10.1001/jama.2013.280386

23. Ramasamy R, Dupree JM, Kovac JR, et al. Risks of testosterone therapy in elderly men. F1000Research 2014;3:11

24. Xu L, Freeman G, Cowling BJ, et al. Testosterone therapy and cardiovascular events among men: A systematic review and meta-analysis of placebo-controlled randomized trials. BMC Med 2013;11:108. http://dx.doi.org/10.1186/1741-7015-11-108

25. Chrysant SG. Effectiveness and safety of phosphodiesterase 5 inhibitors in patients with cardiovascular disease and hypertension. Curr Hypertens Rep 2013;15:475-83. http://dx.doi.org/10.1007/s11906013-0377-9

26. Coviello AD, Kaplan B, Lakshman KM, et al. Effects of graded doses of testosterone on erythropoiesis in healthy young and older men. J Clin Endocrinol Metab 2008;93:914-9. http://dx.doi.org/10.1210/ ic.2007-1692

27. Ajayi AA, Mathur R, Halushka PV. Testosterone increases human platelet thromboxane A2 receptor density and aggregation responses. Circulation 1995;91:2742-7. http://dx.doi.org/10.1161/01. CIR.91.11.2742

28. Kunnas $T$, Solakivi T, Huuskonen $K$, et al. Hematocrit and the risk of coronary heart disease mortality in the TAMRISK study, a 28-year follow-up. Prev Med 2009;49:45-7. http://dx.doi.org/10.1016/i. ypmed.2009.04.015

29. Sorlie PD, Garcia-Palmieri MR, Costas R Jr, et al. Hematocrit and risk of coronary heart disease: The Puerto Rico Health Program. Am Heart J 1981;101:456-61. http://dx.doi.org/10.1016/00028703(81)90136-8

30. Yeap BB, Alfonso H, Chubb $\mathrm{SA}$, et al. In older men an optimal plasma testosterone is associated with reduced all-cause mortality and higher dihydrotestosterone with reduced ischemic heart disease mortality, while estradiol levels do not predict mortality. J Clin Endocrinol Metab 2014;99:E9-18. http://dx.doi. org/10.1210/ic.2013-3272

31. Ramasamy R, Kovac JR, Scovell JM, et al. Re: In older men an optimal plasma testosterone is associated with reduced all-cause mortality and higher dihydrotestosterone with reduced ischemic heart disease mortality, while estradiol levels do not predict mortality. Eur Urol 2014;65:844-5. http://dx.doi. org/10.1016/i.eururo.2013.12.030

Correspondence: Dr. Jason R. Kovac, Urology of Indiana, 12188-A North Meridian St., Suite 200, Carmel, IN 46032; jason.r.kova@gmail.com 